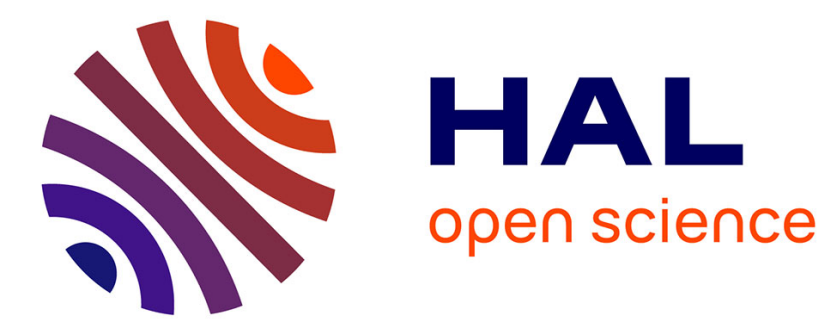

\title{
Uncertainties in CMM Measurements, Control of ISO Specifications
}

\author{
J. Sprauel, J. Linares, J. Bachmann, P. Bourdet
}

\section{To cite this version:}

J. Sprauel, J. Linares, J. Bachmann, P. Bourdet. Uncertainties in CMM Measurements, Control of ISO Specifications. CIRP Annals - Manufacturing Technology, 2003, 52 (1), pp.423-426. 10.1016/S00078506(07)60616-7 . hal-01408960

\section{HAL Id: hal-01408960 https://hal-amu.archives-ouvertes.fr/hal-01408960}

Submitted on 5 Dec 2016

HAL is a multi-disciplinary open access archive for the deposit and dissemination of scientific research documents, whether they are published or not. The documents may come from teaching and research institutions in France or abroad, or from public or private research centers.
L'archive ouverte pluridisciplinaire HAL, est destinée au dépôt et à la diffusion de documents scientifiques de niveau recherche, publiés ou non, émanant des établissements d'enseignement et de recherche français ou étrangers, des laboratoires publics ou privés. 


\title{
Uncertalntles In CMM Measurements, Control of ISO SpecIflcatlons
}

\author{
J.M. Sprauel ${ }^{1}$, J.M.. Llnares ${ }^{1}$, J. Bachmann ${ }^{1}$, P. Bourdet ${ }^{2}$ (1) \\ 1 EA(MS)', I.U.T., Avenue Gasten berger, 13625 Alx en Provence cedex 1, France \\ ${ }^{2}$ E.N.S Cachan, 61 Avenue Présldent Wison, 94230 Cachan, France
}

\begin{abstract}
In the scope of qualty control, accurate evaluatlon of measurement uncertaintles is a real challenge to Improve the use of Coordlnate Measuring Machlnes (CMM). In our work, a new method, based on a statlstical approach of the problem, was therefore developed, to deduce Instantaneous measurement uncertalntles dfrectly from the set of acqulred coordinates. The covarlance matitx of the Int rinsic paramelers whleh characterte each analyzed surface is also evaluated, thus allowing an accurate propagatlon of the measurement uncertaintles to the ISO s pecificatlons to be controlled. The experlments carrled out In our study lllustrate thls new statlstlcal approach and demonstrate is relevance.
\end{abstract}

Keywords:

Coordlnate measuring machlne, Uncertalnty, Statlstleal

\section{INTRODUCTION}

Coordlnate measurng machlnes are now wdely used to qualify Industrial workpleces. Nevertheless, the actual CMM software Is usually restrleted to the determinatlon of mean values. Thls is the case for both the charactert zatlon of Indvidual surfaces and for the determinatlon of geometric deviatlons. However, In accordance wth quat Ity standards, the uncertalinty of each measurement should also be speclfied [1]. Thls becomes Inereasingly Important In Indust rlal routine. For s Imple processes, Ilke callper or mlcrometer measurements, the evaluatlon of uncertalntles by a conventional method as recommended by the GUM [2] Is stralghtforward. However, thls procedure becomes extremely tedlous or even Imposst ble for coordinat e measurements.

Actually, the uncertalntles of such measurements are therefore ether deduced from repeated expensive experiments or estlmated through numerical simulatlons [3,4]. The latter methods requlre however to decompose the measurement process Into a set of elementary functlons and to Identlify all the assoclated Independent random varlables. In addition, the Intrinsle parameters of the analyzed surfaces are then assumed to be Independent one of the other, thus leading to a mong determination of the error bars of the ISO spectifeat lons to be qualffed. Moreover, these methods do not account for uncontrolled ovents and resulting perturbatlons whlch may occur during the acqulsitlon.

Another way to evaluate the uncertalntles of CMM measurements is to use a statlstlcal approach of the problem. In fact, the set of digltized coordinates forms a stat|stlcal sampllng of the true analyzed surface. It contalns therefore some mlxed Informatlon about the distrbution of the material around the ldeal geometrle eloment and about the qually of the measurement. Thls property has already been pointed out by diferent au thors $[5,6,7]$. but has not yet been used to evaluate the uncertalntles of CMM measurements. A new molhod was therefore developed In our laboratory, to deduce Instantaneous measurement uncertalntles dredty from the set of acqulred coordinates [B]. The covarlance matrix of the Intrinsle parameters which charactertze each analyzed surface Is also evaluated, thus allowing an accurate propagatlon of the measurement uncertalntles to the ISO specliftertlons to be controlled. The expertments carrled out In our study will Illustrate thls new statlstlcal approach and will demonstrate the relevance of the methods developed In our work.

\section{PRINCIPLE OF THE METHOD}

\subsection{Fitting of edementary surfaces}

The first step requlred In the treatment of coordlnate measurements is the descriptlon of each digtted surface by an ldeal foature. Each geometrc entlty Is characteried by a set of $p$ Intrinsle parameters a; coordlnates of the centre of the measured surface, cosines of the normal to a plane or of the directlon vector of an axls, radus, angle of a cone, etc. The ftting of the acquired data comes thus to the optlmzatlon of these parameters a. In order to oblen the best layout of the measured coordlnates around the Ideal feature. It is usually based on the minlmzatlon of the distance $d_{k}$ between $N$ acquired points $M_{k}$ and the assoclated geometrle element. Dlfierent procedures are used for that purpose Ilke the elassical least squares method or the Tehebychev cittoflon. In our study, these methods have been extended to a statlstlcal approach of the problem [8].

The distrlbutlon of the measured coordlnates around the Ideal feature Is characterted therefore by lis probabllty denstty functlon $f\left(d_{k}\right)$. According to the maximum Ilkelhood crtterion, the best statlsilcal estlmator's $\theta_{j}$ of the param eters a; have to maximze the conditlonal probablthy $\phi$ of all the realzed Independent measurements:

$\phi=\prod_{k=1}^{N} f\left(d_{k}\right)$ to be maximzed $\Rightarrow \frac{\partial \phi}{\partial \theta_{i}}=0$

We suppose now that all the systematlc errors have been corrected In the acqulred data. Therefore, the deviatlons Included In the measured coordinates just result from the convolution between statlstlcal perturartlons of the coordlnate measuring machlne and the dlstrlbutlon of the matter around the Ideal geometric element. Since the Instrument depends on a great number 
of uncontrolled parameters, the first devation Is usualy assoclated with a normal law. The second componert $\mathbf{s}$ more difricult to deflne. However, for high quallty surfaces, measurements carried out on dffierent Industrial pleces, heve shown that the scattering of the matter around the Ideal geometrk element can then be rea sonably approximated by a Gausslan distrlbutlon. This is a first step of our statlstlcal approach, but other distrlbutlons will be tested In the neap future for rough surfaces. Under these assumptlons, the llkellhood crtterion simplfles to the classical least squares method and the optrmbatlon condilons become:

$$
\phi=\left(\frac{1}{\sigma \sqrt{2 \pi}}\right)^{N} \operatorname{Exp}\left[-\frac{1}{2} \sum_{k=1}^{N}\left(\frac{d_{k}}{\sigma}\right)^{2}\right] \Rightarrow \sum_{k=1}^{N} d_{k} \frac{\partial d_{k}}{\partial \theta_{i}}=0
$$

If the $p$ parameters $\theta_{j}$ of the geometric element assoct ated to the digltzed surface were perfectly defhed, the standard deviatlon $\sigma$ could also be estlmated in the same way:

$$
\frac{\partial \phi}{\partial \hat{\sigma}}=0 \Rightarrow \hat{\sigma}=\sqrt{\frac{1}{N} \sum_{k=1}^{N} d_{k}^{2}}
$$

However, such estlmator would lead to a blased evaluetlon of $\sigma$, because a set of p paramelers $\theta$, has already been dertved from the acqured data. Therefore, the standard devation of the measurement has to be computed with the following expression, also called residue of the least squares optlmzatlon:

$$
\hat{\sigma}=\sqrt{\frac{1}{N-p} \sum_{k=1}^{N} d_{k}^{2}}
$$

Thls deviatlon $\hat{\sigma}$ can be propagated to deduce the covarlance matrix of the estlmated parameters $a_{i}$, using equatlon (2) and the classleal differentlal expresslons of the uncertalntles [2]. From the dlagonal compenents of the covarlance matrx, the error bars of $\theta_{i}$ are then easlly caleulated, since the statlstleal distribution of these random varlables corresponds to a Flsher-Student law.

\subsection{Uncertalntiss of I50 1101 specificattons}

The covarlance matrx detemlned on each elementary feature can now be used to propagate the standard deviatlons of the flted surfaces to any derived geometrk element. The uncertalntles of the dimensions and geometric devatlons to be vertfed can thus be evaluated. At present, however, our method restrets to the cortrol of ISo 1101 speclficatlons. According to thls standard, each dmersion and geometric error is then qualffed by a distance $\delta$. Thls distance $\delta$ is detived from difierert geometrle construetlons and Is llnked to $n$ of the parame ters e, determined by the fitting of the elementary features. Using a difrerentla formulation of its standard devatlon $\sigma_{5}$ it comes:

$$
\sigma_{\sigma}^{2}=\sum_{i=1}^{n} \sum_{j=1}^{n} \frac{\partial \delta}{\partial \theta_{i}} \operatorname{Cov}\left(\theta_{i}, \theta_{j}\right) \frac{\partial \delta}{\partial \theta_{j}}
$$

Introducing the Jacoblan matrtx $\mathrm{J}$ of the dlstance $\delta$ and its transpose $J$, thls expression can also be rewitten as a mattx product:

$$
\sigma_{\delta}^{2}=\mathrm{JCJ} \text {, where } \mathrm{J}_{i}=\frac{\partial \sigma}{\partial \theta_{i}} \text { and } c_{\|}=\operatorname{Cov}\left(\theta_{i}, \theta_{j}\right)
$$

The evaluatlon of the standard devation $\sigma_{5}$ comes thus to the determinatlon of the Jacoblan matrx $\mathrm{J}$. For that purpose, a generle algorthm has been developed whlch allows computing its components whatever geometric constructlon has been used to dertve the distance $\delta$.

\section{EXPERIMENTAL APPLIGATION}

In order to valldate our new statlstlcal approach, dffierent experiments have been carrled out In our baboratory using a coordinate measuring machine equlpped with a touch trigger probe system mounted on an Indexing head. All the measurements have been conducted $h$ programmed automatle mode. The acqulstllon speed was kept constant and set to half the maximum samplling rate of the coordlnato-measuring machine.

\subsection{Uncertalntes of single polnt measurements}

The unce rtantles obtalned In single point measurements have been characterted first to define the random perturbatlons of the coordlnate measuring machine. A MCG checking gauge was used for that purpose with a plvotIng arm of $151 \mathrm{~mm}$ (Flgure 1).

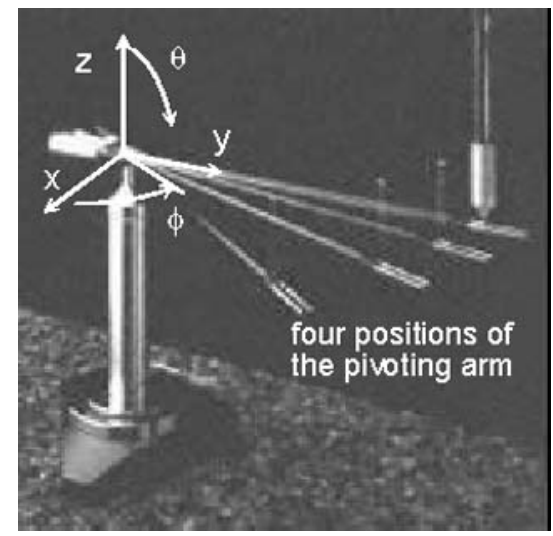

Flgure 1: Machlne checking gauge system.

Such a system, designed to test the volumetrk performance of a coordlnate measurng machne, permlts analyzing the reference plvoting arm In a great range of $(0.8)$ Inclinatlons. Single polnt measurements were thus carFled out for 24 evenly distrlbuted directlons. The acqulsttlons were repeated 144 tlmes. Thls allowed, for each Incllnatlon of the system, to compute the covarlance matrx of the dlgittzed coordlnates, using classleal statlstlcal formulae. Since the polnts were always acqulred $h$ the directlon nom al to the plvoting arm, all the components of this matrx were found of second order, except for the directlon of measurement. The standard deviatlon of the plvothg radus is thus surfielent to charactertze the acqulstions. The results are presented In Table 1.

\begin{tabular}{|c|c|c|c|}
\cline { 2 - 4 } \multicolumn{1}{c|}{} & \multicolumn{3}{c|}{$\theta(0)$} \\
\hline$\phi()$ & 45 & 90 & 135 \\
\hline 180 & 0,75 & $0,6 \theta$ & 0,70 \\
\hline 135 & 0,80 & 0,72 & 0,93 \\
\hline 90 & 0,69 & 0,68 & 1,00 \\
\hline 45 & 0,80 & 0,76 & 0,75 \\
\hline 0 & 0,78 & 0,65 & 0,85 \\
\hline-45 & 0,80 & 0,66 & 0,67 \\
\hline-90 & 0,95 & 0,61 & 0,66 \\
\hline-135 & 0,94 & 0,83 & 0,92 \\
\hline
\end{tabular}

Table 1: Standard devations of measurement In $\mu \mathrm{m}$. 
With a confidence level of $99 \%$, Fisher tests applied to th is data demonstrate that the standard deviation can be considered as constant for all the scanned directions. The whole acquired points could therefore be used to characterize the stochastic noise of our coordinate measuring machine. Figure 2 shows the histogram of the deviations measured in this first experiment.

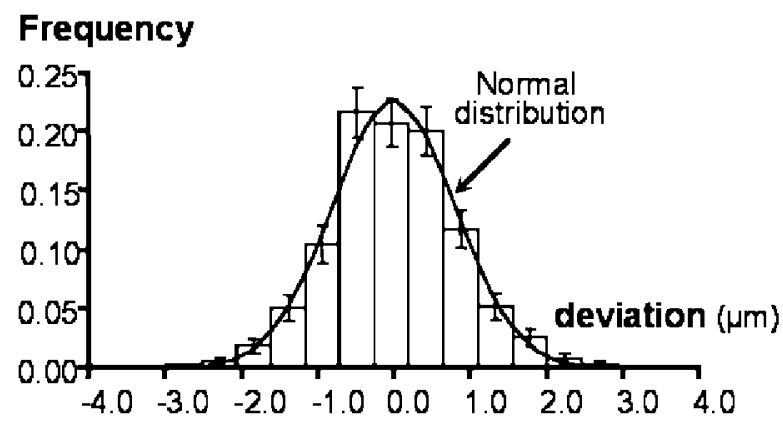

Figure 2: Histogram of the stochastic noise of the CMM. This graph demonstrates that the random perturbations of our machine can be accurately described by a Normal distribution.

\subsection{Uncertainties of elementary features}

In the second step of our experiments the artifact of Figure 3 was tested to check our new statistical approach.

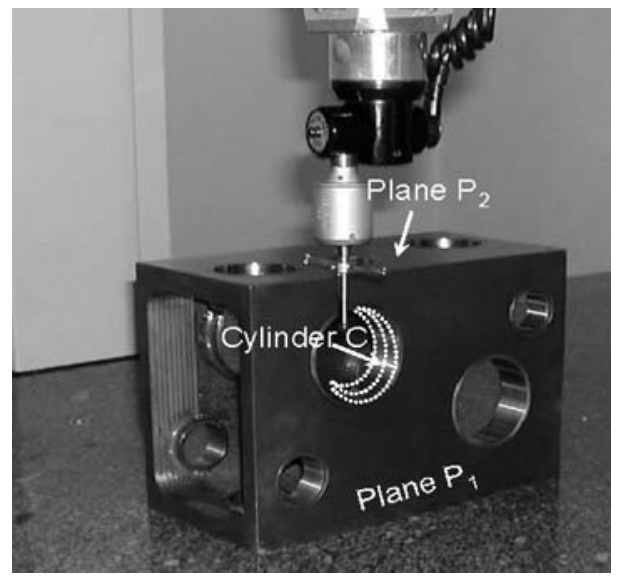

Figure 3: Artifact used in our experiment

For this sample, all the planes were acquired in 20 evenly distributed points. The cylinders were characterized by three circles defined by 16 points. The measurements were repeated 151 times to allow the standard deviations of the results to be defined in a classical way. Figure 4 shows the results obtained for the testing of Plane $\mathrm{P}_{1}$ which is a surface of high quality.

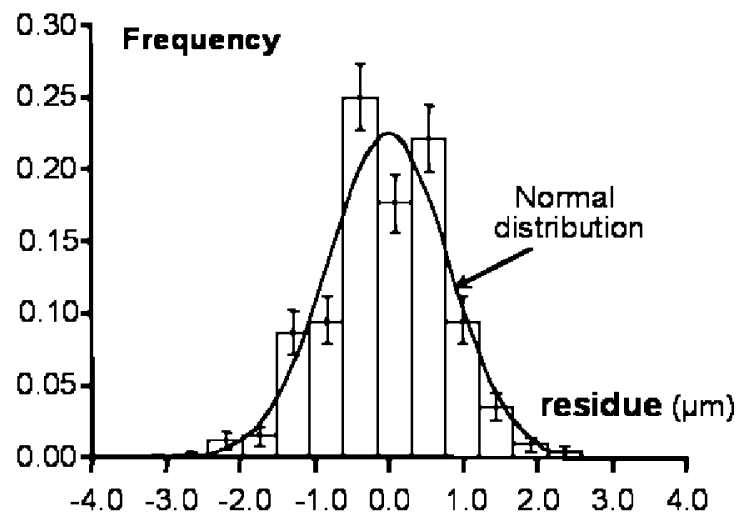

Figure 4: Histogram of the residues of plane $P_{1}$
For this feature, the standard deviations were found to be the same for all the acquired points. The whole $151 \mathrm{x}$ 20 digitized coordinates of the experiment were therefore used to define the histogram of the least squares optimization residues. This result has been compared to the data obtained for single point acquisitions (Figure 5).

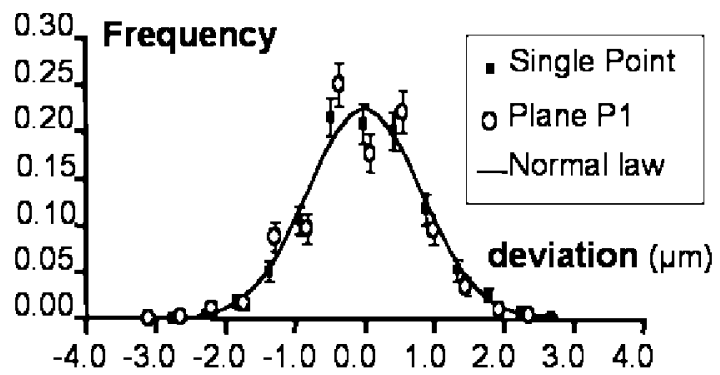

Figure 5: Comparison between the deviations obtained for single point acquisitions and for testing of Plane $P_{9}$.

Both distributions are practically the same. This means that for surfaces with low form defect, like plane $P_{1}$, the least squares fitting residues are directly linked to the stochastic noise of the coordinate measuring machine. It demonstrates clearly that the random deviations of the CMM are included in the set of acquired coordimates and can therefore be characterized by our statistical approach.

The next experimental part is now dedicated to the control of the location deviation between cylinder $\mathrm{C}$ and plane $P_{2}$. Three circles $C_{1}, C_{2}, C_{3}$ have therefore been measured on the cylindrical surface to define the axis of this entity. Figure 6 shows the histogram of the least squares residues obtained for the first acquired circle $\mathrm{C}_{1}$.

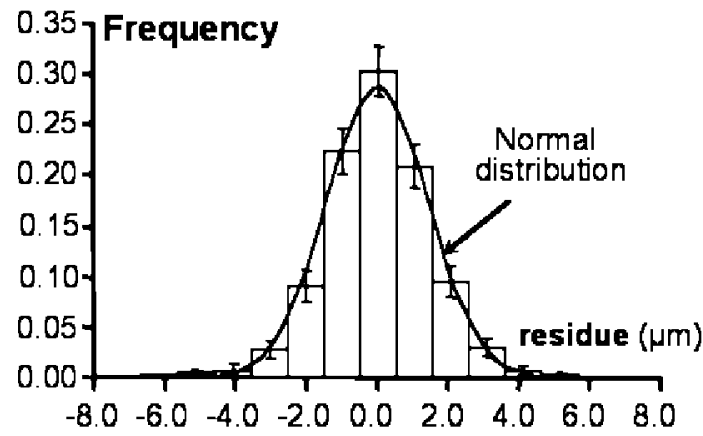

Figure 6: Distribution of least squares residues of $\mathrm{C}_{1}$

Again, the distribution of the least squares residues is Gaussian. However, in that case, its standard deviation is about two times greater than the value found for single point measurements. This is due to the form defect of the cylindrical surface, which was evaluated to $11 \mu \mathrm{m}$. Such result demonstrates now that the acquired coordinates also include statistical information about the distribution of the matter around the perfect ideal feature which is fitted to the measured points. The same type of results is abtained too for the two other circles.

It has however to be pointed out that the layout of the matter around the fitted feature cannot always be described by a normal distribution because it closely depends on the manufacturing process. In the general case the deviations included in the measured coordinates will then result from the convolution between the Gaussian contribution of the coordinate measuring machine and the process related geometrical surface defects of the analyzed sample.

The characterization of the location deviation between cylinder $C$ and plane $P_{2}$ required finally to acquire this last surface 


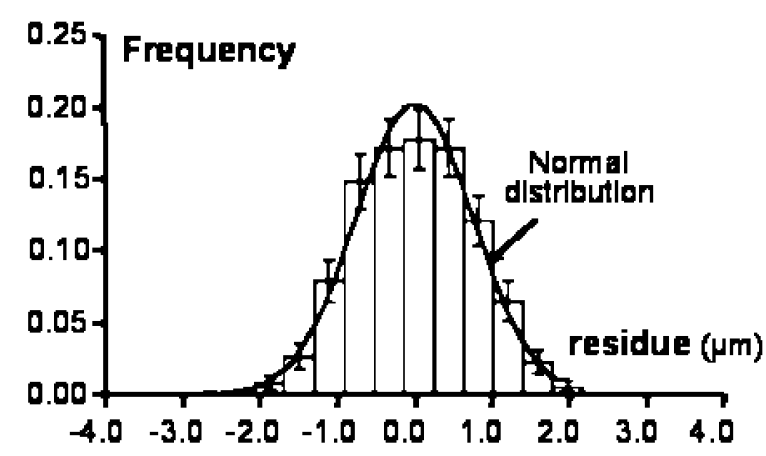

Flgure 7: Histogram of the residues of plane $P_{2}$. Figure 7 shows the hlstogram obtalned for thls entlty. As for plane $P_{1}$, due to the low form defect of the surface, the residues of the least squares fitting correspond to the stochastlc nolse of the coordlnate measuring machlne.

\subsection{Uncertalnties of geometrle devations}

From each set of acqulsitlons carrled out on clrcles $C_{1}$ $C_{2}, C_{3}$ and plane $P_{2}$, the geometrk errors of cylinder $C$ could finaly be defined. According to ISO 1101 startdard, the location devietlon of cylnder $C$ has been doduced from the distances between the centers of clrcles $C_{1}, C_{2}, C_{3}$ and plane $P_{2}$. Since the experlment was repeated 151 times, the standard devatlons of these dlstances could also be computed In a classical way.

On the other hand, as already polnted out, our new statlstlcal approach allows asso to estimate the covart ance mattx of the Intrinsle paramelers evaluated for each elementary surface. Thls hiomation has been propagated to the calculated dlstances, thus defining the standard deviatlons In a second manner. For each set of data, these values are then Just dertved from the 20 points acquired to charactertze plane $P_{2}$ and the $3 \times 16$ coordlnates which define cylnder $C$. The results are presented In table 2.

\begin{tabular}{|c|c|c|}
\cline { 2 - 3 } \multicolumn{1}{c|}{} & \multicolumn{2}{c|}{ standard dovation $(\mu \mathrm{m})$} \\
\cline { 2 - 3 } \multicolumn{1}{c|}{} & $\begin{array}{c}\text { classical } \\
\text { method }\end{array}$ & $\begin{array}{c}\text { deduced from } \\
\text { residue }\end{array}$ \\
\hline $\begin{array}{c}\text { Distance } \\
\mathbf{C}_{1} / P_{2}\end{array}$ & 1,30 & 1,51 \\
\hline $\begin{array}{c}\text { Distance } \\
\mathbf{C}_{2} / P_{2}\end{array}$ & 1,39 & 1,35 \\
\hline $\begin{array}{c}\text { DIstance } \\
\mathbf{C}_{3} / P_{2}\end{array}$ & 1,52 & 1,37 \\
\hline
\end{tabular}

Table 2: Standard devatlons of the measured distances.

The devlatlons deduced from the resldue of the least squares optlmbatlon were of the same order for all the set of acqulred surfaces. Only thelr mean values were therefore reported In thls table. The results show cleaty that the Instantaneous standard deviations defined trough our new statlstlcal approach are very close to the values calculated by a classlcal method based on ro peated measurements. Thls demenstrates cleary the relevance of our method.

\section{CONCLUSION}

In our work a new statlstlc approach has been deveroped to evaluate Instantaneous uncertalntles of coordnate measurements. These uncertalntles are dertved from the residue between the perfect Ideal features fitted to the acqulred points and the related olghtzed coordnates. The method shows that due to the form defects of the measured surface, the deviatlens of the results obtalned with a glven algorthm not only depend on the stochastle nolse of the CMM but are also Ilnked to the points dstrbution selected on the measured surface. The experlmental results obtalned In our study demort strate clearty that the uncertalntles derved from a single measurement using our statlstlcal method are very close to the values defined by repeated tests. The Instartano ous uncertalnty ovaluated through our approach will thus give a relevart Indleator allowing to check a gtven CMM control process In order to opilmze its procedures and experimental conditlons.

At present, the method Is llmited to the verficatlon of ISO 1101 tolerances and geometrle devations. The statlstlcal approach will now be extended to the control of envelop requlrements.

\section{REFERENCES}

[1] Sinvasan, V., 2001, An Integrated vew of Geometrkal Product Speclficatlon and Vertileatlon, Proceedlings of the 7 th CIRP Seminar on Computer-Alded Toleranelng: 7-17.

[2] 1993, Gude to the Expression of Uncertalnty in Measurement, First Editlon, Intematlonal Organizatlon for Standardzatlon.

[3] Balsamo, A. Dl Clommo, M, Mugno, M., Rebaglla, B.I., Clccl, E., Grella, R., 1999, Evaluatlon of CMM Uncertalnty through Monte Carlo SImulatlons, Art nals of the CIRP, $48 / 1: 425-428$

(4) Schwenke, H., Slebert, B.R.L., Wwdele F., Kunzmann H., 2000, Assessment of Uncertalntles In Dimenslenal Metrology by Monte Carlo Simulatlon, Annals of the CIRP, 49/1:395-397.]

[5] Kurfess T., Banks, D.L., 1995, Statlstlcal verfflcatlon of contormance to geometrtc tolerance, computer Alded Design, 27/5:353-361

[6] Yau, H.T., 1997, Evaluatlon and uncertalnty analy sls of vectorlal tolerances, Preclslon englneering. $20: 123-137$

[7] Chol, w., Kurfess, T., 1998, Uncertalnty of extreme fit evaluatlon for threo-dmenslonal measurement data antysls, Computer Alded Design, 30/7:549557.

[8] Sprauel J.M., LInares, J.M.. Bourdet P., 2001, Contrbutlon of nonllnear optlmzatlon to the determination of measurem ert uncertalntles, ProceedIngs of the 7th CIRP Seminar on Computer-Alded Toleranclng:285-291. 